\title{
AMELIORATION OF GENTAMICIN-INDUCED RENAL DAMAGE IN RATS BY ETHANOL EXTRACT OF THE WHOLE PLANT BIOPHYTUM SENSITIVUM (LINN.) DC
}

\author{
ABHIRAMA B. R. $\mathbf{a}^{*}$, SHANMUGA SUNDARAM $\mathbf{R}^{\mathbf{b}}$, RAJU $\mathbf{A}^{\mathbf{c}^{*}}$ \\ ${ }^{a}$ Department of Pharmaceutical Chemistry, J.K.K. Nattraja College of Pharmacy, Komarapalayam 638138, Tamilnadu, India, ${ }^{b * D e p a r t m e n t}$ \\ of Pharmacology, J.K.K. Nattraja College of Pharmacy, Komarapalayam 638138, Tamilnadu, India. Affiliated to Tamilnadu \\ Dr.M.G.R.Medical University, Chennai 600032, Tamilnadu, India, c Department of Pharmacology, St Joseph College of Pharmacy , \\ Cherthala, Kerala. Affiliated to KUHS, Trissur, Kerala.
}

Email: abhiramabr266@gmail.com

Received: 27 Feb 2018 Revised and Accepted: 14 Apr 2018

\section{ABSTRACT}

Objective: Present study was undertaken to investigate the nephroprotective activity of whole plant ethanol extract of Biophytum sensitivum Linn DC (B. sensitivum; EEBS) on gentamicin induced-nephrotoxicity in Wistar albino rats.

Methods: Animals were divided into five groups, containing six animals in each. Gentamicin (GM) $100 \mathrm{mg} / \mathrm{kg} / \mathrm{d}$; $i . p$., was given to all groups except normal control to induce nephrotoxicity for a period of $8 \mathrm{~d}$ in rats. Animals in Group I served as control and Group II as GM-treated or nephrotoxic control. Group III received standard quercetin ( $50 \mathrm{mg} / \mathrm{kg} ; p . o$.); group IV received EEBS (250 mg/kg; p. o.) and group V received EEBS ( $500 \mathrm{mg} / \mathrm{kg}$; p. o.), for $8 \mathrm{~d}$. Several renal functional tests and injury markers such as a change in body weight, water intake, urine volume and pH, urinary levels of total protein, albumin, sodium, potassium, calcium and magnesium were measured. Different hematological parameters including, red blood cells (RBC), hemoglobin (Hb), packed cell volume (PCV), mean corpuscular haemoglobin (MCH), white blood corpuscles (WBC), lymphocyte, monocyte, polymorphs and eosinophil were also analyzed.

Results: The results revealed that co-administration of EEBS at 250 and $500 \mathrm{mg} / \mathrm{kg}$ significantly reduced the urinary excretion of total protein $(4.05 \pm 0.04,3.53 \pm 0.05 \mathrm{~g} / \mathrm{dl})$, albumin $(0.81 \pm 0.08,0.71 \pm 0.00 \mathrm{~g} / \mathrm{dl})$, calcium $(8.05 \pm 0.05,7.81 \pm 0.06 \mathrm{mg} / \mathrm{dl})$ and magnesium $(0.79 \pm 0.05,0.77 \pm 0.06$ $\mathrm{mg} / \mathrm{dl})$ respectively. EEBS treatment in group IV and $\mathrm{V}$ animals produced a significant increase in body weight $(2.58 \pm 0.17,2.52 \pm 0.22 \mathrm{~g}), \mathrm{water}$ intake $(17.35 \pm 0.82,17.87 \pm 0.86 \mathrm{ml} / 24 \mathrm{~h})$ urine output $(7.24 \pm 0.15,7.88 \pm 0.08 \mathrm{ml} / 24 \mathrm{~h})$, compared to animals in group II. Co-therapy with both doses of extracts also showed significant increase in RBC $\left(6.85 \pm 0.31,7.10 \pm 0.43 \mathrm{million} / \mathrm{mm}^{3}\right) \mathrm{Hb}(13.96 \pm 0.21,13.83 \pm 0.31 \mathrm{~g} / \mathrm{dl}), \mathrm{MCH}(20.45 \pm 0.49$ $20.67 \pm 0.51 \mathrm{pg})$ and PCV (38.29 $\pm 0.42,38.53 \pm 0.20 \%)$ levels, whereas WBC $\left(8.24 \pm 0.21,8.15 \pm 0.101 \mathrm{X} 10^{3} / \mathrm{mm}^{3}\right)$ and polymorphs $(14.19 \pm 0.20$ $14.05 \pm 0.11 \%$ ) levels were found to be significantly reduced respectively in animals than those in toxic control group.

Conclusion: This study substantiated and confirmed the ethnomedical usefulness of B. sensitivum as a nephroprotective and antioxidant agent

Keywords: Biophytum sensitivum, Gentamicin, Hematological parameters, Nephroprotection, Quercetin

(C) 2018 The Authors. Published by Innovare Academic Sciences Pvt Ltd. This is an open access article under the CC BY license (http://creativecommons.org/licenses/by/4.0/] DOI: http://dx.doi.org/10.22159/ijpps.2018v10i5.25514

\section{INTRODUCTION}

Gentamicin (GM) is a typical aminoglycoside antibiotic which provides an effective treatment against life-threatening gram-negative infections [1]. It is still widely used in clinical practice because of its low cost and efficacy, even though less nephrotoxic antibiotics are available [2]. However, $30 \%$ of patients treated with GM, for more than $7 \mathrm{~d}$ show some signs of nephrotoxicity [3]. Lowering level of red blood cells (RBC), hemoglobin (Hb), mean corpuscular haemoglobin $(\mathrm{MCH})$, packed cell volume (PCV), lymphocytes in rats treated with the nephrotoxic drug may be due to the imbalance between the rate of normal production of erythropoietin and their catabolism/ destruction. Lowering of RBC count indicated that these nephrotoxic drugs might induce a direct toxic effect on red blood cells thereby, reducing its lifespan. These deleterious effects perhaps as consequence of the generation of reactive oxygen species. It has been reported that GM induces apoptosis, necrosis, and oxidative stress due to the accumulation of drug at a concentration of 5-50 times higher than plasma in the tubular renal cell [4]. Lipid peroxidation (LPO) mediated by reactive oxygen species (ROS) has been suggested as a causative agent of cell death [5]. GM-induced renal damage is a widely used model for inducing nephrotoxicity in experimental animals [6].

Medicinal plants have curative properties on drug-induced nephrotoxicity due to the presence of various complex chemical substances. Ancient literature has prescribed that co-administration of various medicinal plants possessing nephroprotective activity along with different nephrotoxic agents may attenuate its toxicity [7].
Biophytum sensitivum Linn. DC (B. sensitivum; Vernacular names: Tamil-Nilaccurunki, Tintaanaalee; Malayalam-Mukkutti; Hindi-Lajalu, Lajjaalu, Lakshmana) belongs to family Oxalidaceae [8]. Phytochemical investigations of various extracts of $B$. sensitivum had revealed the presence of large amount of phenolic and polyphenolic compounds, saponins, polysaccharides, pectin and essential oils. The principle bioactive constituents are bioflavonoids like amentoflavone, with trace amounts of cupressoflavone, luteolin, isoorientin and isovitexin [9]. It has been used as a traditional folk medicine in various ailments. Grounded leaves shows diuretic activity and powdered form is indicated for urolithiasis [10]. Recently antioxidant [11], antibacterial [12], antidiabetic [13], antitumour [14], anti-inflammatory [15] and cardio protective activities [16] were reported. Therefore, as the search for the nephroprotective drug from natural sources has gained immense potential, this study was aimed to investigate the in vivo neuroprotective activity of ethanol extract of B. sensitivum (EEBS) in GM-induced nephrotoxicity in Wistar albino rats.

\section{MATERIALS AND METHODS}

\section{Animals}

Adult male albino rats of Wister strain, weighing between 150-200 g were housed under standard laboratory condition of 12:12 dark and light cycle, $50 \%$ humidity and temperature $25 \pm 2{ }^{\circ} \mathrm{C}$. They were allowed free access to standard commercial rat feed pellets (SAI Animal Feed Ltd., Bangalore, India) and were given water ad libitum. The animals were acclimatized to laboratory condition for $7 \mathrm{~d}$ before 
the commencement of experiments. Ethical clearance (KMCRET/Ph. D/12/2015-16) was obtained from Institutional Animals Ethics Committee (IAEC). The rats received human care according to the guideline of Committee for the Purpose of Control and Supervision of Experiments on Animals (CPCSEA).

\section{Drugs and chemicals}

Gentamicin was obtained from Central Drug House (CDH), New Delhi, India and quercetin from Microlabs (Pondicherry, India). All other chemicals and reagents used in this study were of analytical grade.

\section{Animal grouping}

GM-induced nephrotoxicity model was used to assess the nephroprotective activity in albino Wistar rats $[17,18]$. Animals were divided into 5 groups, designated as Group I, II, III, IV and V, containing 6 animals each. Animals in Group I served as control and received normal saline for $8 \mathrm{~d}$. GM $(100 \mathrm{mg} / \mathrm{kg} / \mathrm{d} ; \quad i . \quad p$. $)$ was administered for a period of $8 \mathrm{~d}$ to animals in Group II to $\mathrm{V}$ for inducing nephrotoxicity. Group II served as GM-treated or nephrotoxic control and received vehicle (1\% tween 80$)$. Group III received standard quercetin $(50 \mathrm{mg} / \mathrm{kg} ;$ p.o. $)$ for $8 \mathrm{~d}$. Group IV received EEBS ( $250 \mathrm{mg} / \mathrm{kg}$; p. o.) and Group V received EEBS (500 $\mathrm{mg} / \mathrm{kg}$; p.o.), for $8 \mathrm{~d}$.

\section{Plant-source and identification}

The whole plant, B. sensitivum was collected from Shevaroy Hills, Salem District, Tamil Nadu, India and was taxonomically identified and authenticated by Dr. A. Balasubramanian, Executive Director, ABS Botanical conservation, Research and Training Centre, Kaaripatti, Salem (Dt.) Tamilnadu (Ref. No-AUT/JKK/095).

\section{Preparation of plant extract}

The whole plant was washed and shade dried for about $3 \mathrm{w}$. Dried plant was coarsely powdered, sieved (mesh size $=40$ ) and stored in an air-tight container at room temperature. Powdered plant material $(500 \mathrm{~g})$ was sequentially extracted with petroleum ether $\left(60-80^{\circ} \mathrm{C}\right)$ for defatting and then with $70 \%$ ethanol using Soxhlation method. The extract was then filtered and evaporated to dryness in a water bath. After weighing, the dried extract was stored in air-tight container for further use.

\section{Phytochemical investigation}

The EEBS was tested for the presence of alkaloids, flavonoids, phenolic compounds, tannins, glycosides, saponins, terpenoids, steroids, protein, carbohydrates and fixed oils using the standard procedures $[19,20]$.

\section{Acute toxicity studies}

Acute oral toxicity studies were not performed as studies of ethanolic extract of the whole plant B. sensitivum have already been reported. The previous study by Anidya et al., [21] used $5000 \mathrm{mg} / \mathrm{kg}$ dose of EEBS as a higher dose in albino rats. Hence, one-tenth of this dose, $500 \mathrm{mg} / \mathrm{kg}$ (higher dose) and lower dose as $250 \mathrm{mg} / \mathrm{kg}$ have been selected for the present study.

\section{Analysis of urine}

At the end of treatment schedule, the animals were housed in individual metabolic cages and $24 \mathrm{~h}$ urine samples were collected on $9^{\text {th }} \mathrm{d}$. Change in body weight, water intake, urine volume and $\mathrm{pH}$ were recorded. A drop of concentrated hydrochloric acid was added to the collected urine and stored at $4{ }^{\circ} \mathrm{C}$. Urine was then analyzed for total protein [22], albumin [23], sodium [24], potassium [25], calcium [26], and magnesium [27].

\section{Analysis of blood}

After collecting the urine, the animals were anaesthetized with ketamine $\mathrm{HCl}$ and blood was collected from tail vein under mild anesthesia. Various haematological parameters including, red blood cells (RBCs), hemoglobin $(\mathrm{Hb})$, packed cell volume (PCV), mean corpuscular haemoglobin $(\mathrm{MCH})$, white blood corpuscles (WBC), lymphocyte, monocyte, polymorphs and eosinophils were also analyzed [28, 29].

\section{Histopathological studies}

The right kidney was fixed in $10 \%$ neutral buffered formalin, processed in a series of graded alcohol and xylene, embedded in paraffin wax, sectioned at $5 \mu \mathrm{m}$ and stained with haematoxylin and eosin (H and $\mathrm{E}$ ) for histopathological examination

\section{Statistical analysis}

The results were expressed as mean \pm SEM. Statistical significance between means was analyzed by one-way analysis of variance (ANOVA) followed by "Dunnett's test." $\mathrm{P}$ values $<0.05$ were considered statistically significant.

\section{RESULTS}

The yields of petroleum ether and ethanol extracts were $4.92 \% \mathrm{w} / \mathrm{w}$ and $12.54 \% \mathrm{w} / \mathrm{w}$ respectively. The preliminary phytochemical investigation indicated that EEBS showed the presence of carbohydrates, alkaloids, steroids, saponins, proteins, amino acids, flavonoids, tannins, phenolic compounds and fixed oils.

\section{Effect of EEBS on general and urinary parameters of control and experimental animals}

Table 1 depicted the effect of EEBS on general and urinary parameters of control and experimental animals that were obtained at the end of the experiment in each group. Body weight was measured before starting the experiment. The animals in the control groups gained $3.06 \pm 0.23$ g of body weight, while GM-treated animals (group II) gained only $1.50 \pm 0.11 \mathrm{~g}$ of body weight. Body weight of animals in group IV and group V gained $2.58 \pm 0.17 \mathrm{~g}$ and $2.52 \pm 0.22 \mathrm{~g}$ respectively. $24 \mathrm{~h}$ urine volume in the GM-treated group was found to be reduced in comparison to control group ( $\mathrm{p}<0.01)$. Supplementation of quercetin $(50 \mathrm{mg} / \mathrm{kg})$ and EEBS (250 and $500 \mathrm{mg} / \mathrm{kg}$ ) to GM-treated rats significantly increased urine output almost similar to the animals in control group. However, water intake was significantly $(p<0.05)$ increased only in animals co-administered with $500 \mathrm{mg} / \mathrm{kg}$ of EEBS. Urinary $\mathrm{pH}$ in the GM-treated group was found to be $6.6 \pm 0.04$ which revealed no significant $(p>0.05)$ changes in urinary $\mathrm{pH}$ compared to animals in other groups (table 1, group II). GM-treated rats showed a marked increase in urinary protein excretion $4.52 \pm 0.02 \mathrm{~g} / \mathrm{dl}$ vs controls $(3.65 \pm 0.01 \mathrm{~g} / \mathrm{dl})$ and albumin $0.84 \pm 0.06 \mathrm{~g} / \mathrm{dl}$ vs. controls $(0.77 \pm 0.01 \mathrm{~g} / \mathrm{dl})$ excretion. Co-treatment with EEBS $(250$ or 500 $\mathrm{mg} / \mathrm{kg})$ or querticin $50 \mathrm{mg} / \mathrm{kg}$ significantly $(\mathrm{p}<0.01)$ reduced the incidence of proteinuria in rats compared to GM-treated rats (table 1 , group III, IV, V). Significant $(\mathrm{p}<0.01)$ reduction in urinary albumin levels were observed only in animals treated with standard or EEBS at higher concentration. Urinary excretion of calcium and magnesium levels $(p<0.01)$ were found to be much higher in group II animals compared to animals in control group. Co-treatment with quercetin or EEBS $[250 \mathrm{mg} / \mathrm{kg}$ and $500 \mathrm{mg} / \mathrm{kg}$ ] significantly decreased urinary calcium $(\mathrm{p}<0.001)$ and magnesium $(\mathrm{p}<0.01)$ excretion compared to GM-treated animals.

\section{Effect of EEBS on hematological parameters of control and experimental animals}

Table 2 demonstrated that $\mathrm{Hb}, \mathrm{PCV}(\mathrm{p}<0.001)$, RBCs and MCH levels $(p<0.01)$ were significantly lower in rats treated with GM than those in the control group. WBC $(\mathrm{p}<0.01)$ and polymorphs $(\mathrm{p}<0.001)$ were found to be significantly elevated in rats in group II, compared to animals in group I. Results revealed that the animals co-treated with standard/extract caused a significant $(\mathrm{p}<0.01)$ increase in RBCs, Hb and MCH level. PCV was found to be increased only in animals cotreated with quercetin/high dose of EEBS $(\mathrm{p}<0.01)$. Total WBC and polymorphs were found to be significantly reduced in animals cotreated with standard/extract $(\mathrm{p}<0.01)$.

\section{Results of histopathological studies}

Histopathological analysis revealed the normal morphology of glomeruli, tubules, blood vessels and interstitium of animals in control group. However, a photomicrograph of a histological section of both cortex and medulla of GM-treated rat kidney showed mesangial hypercellularity in the glomerulus, tubular necrosis and tubular degeneration. Blood vessels showed congestion whereas interstitium showed no significant pathology. Animals treated with 
GM and quercetin showed mild mesangial hyper cellularity in the glomerulus and mild congestion in blood vessels. Interstitium and tubules showed no significant pathology. Histological section of rat kidney (cortex and medulla) treated with low dose of the extract $(250 \mathrm{mg} / \mathrm{kg}$ b.w.) indicated moderate tubular necrosis, tubular degeneration, and cytoplasmic vacuolation in the proximal tubules.
Glomerulus showed mild mesangial hypercellularity and the interstitium showed no significant pathology. Histological section of kidney of rat in group V treated with EEBS at a dose of $500 \mathrm{mg} / \mathrm{kg}$ showed regenerative changes in tubules and glomeruli. Glomeruli and interstitium showed normal morphology. Tubules showed no significant pathology except mild cytoplasmic vacuolation in tubules.

Table 1: Effect of EEBS on general and urinary parameters of control and experimental animals

\begin{tabular}{|c|c|c|c|c|c|}
\hline $\begin{array}{l}\text { Parameters Studied } \\
\text { (Unit) }\end{array}$ & $\begin{array}{l}\text { Group I } \\
\text { Normal control }\end{array}$ & $\begin{array}{l}\text { Group II } \\
\text { GM } 100 \mathrm{mg} / \mathrm{kg}\end{array}$ & $\begin{array}{l}\text { GroupIII GM+QTN } \\
50 \mathrm{mg} / \mathrm{kg}\end{array}$ & $\begin{array}{l}\text { Group IV GM+EEBS } \\
250 \mathrm{mg} / \mathrm{kg}\end{array}$ & $\begin{array}{l}\text { Group V GM+EEBS } \\
500 \mathrm{mg} / \mathrm{kg}\end{array}$ \\
\hline \multicolumn{6}{|l|}{ General } \\
\hline Change in body wt (g) & $3.06 \pm 0.23$ & $1.50 \pm 0.11^{* * a}$ & $3.38 \pm 0.14^{* * * b}$ & $2.58 \pm 0.17^{* * b}$ & $2.52 \pm 0.22^{* * b}$ \\
\hline Water intake $(\mathrm{ml} / 24 \mathrm{~h})$ & $12.35 \pm 0.57$ & $14.53 \pm 0.76^{\mathrm{ns}}$ & $17.35 \pm 0.82^{\mathrm{ns}}$ & $17.35 \pm 0.82^{\mathrm{ns}}$ & $17.87 \pm 0.86^{* b}$ \\
\hline \multicolumn{6}{|l|}{ Urinary } \\
\hline Urine volume $(\mathrm{ml} / 24 \mathrm{~h})$ & $7.73 \pm 0.14$ & $5.74 \pm 0.20^{* * a}$ & $7.62 \pm 0.29^{* * b}$ & $7.24 \pm 0.15^{* * b}$ & $7.88 \pm 0.08^{* * * b}$ \\
\hline Urine $\mathrm{pH}$ & $6.8 \pm 0.05$ & $6.6 \pm 0.04^{\mathrm{ns}}$ & $6.8 \pm 0.01^{\mathrm{ns}}$ & $6.7 \pm 0.06^{\mathrm{ns}}$ & $6.8 \pm 0.06^{\mathrm{ns}}$ \\
\hline Total protein $(\mathrm{g} / \mathrm{dl})$ & $3.65 \pm 0.01$ & $4.52 \pm 0.02^{* * a}$ & $3.55 \pm 0.01^{* * b}$ & $4.05 \pm 0.04^{* * b}$ & $3.53 \pm 0.05^{* * b}$ \\
\hline Albumin (g/dl) & $0.77 \pm 0.01$ & $0.84 \pm 0.06^{* * a}$ & $0.63 \pm 0.01^{* * b}$ & $0.81 \pm 0.08^{\mathrm{ns}}$ & $0.71 \pm 0.00^{* * b}$ \\
\hline Sodium (mmol/l) & $74.16 \pm 1.86$ & $75.16 \pm 1.87^{\mathrm{ns}}$ & $71.66 \pm 0.33^{\mathrm{ns}}$ & $74.33 \pm 1.92^{\mathrm{ns}}$ & $74.30 \pm 1.49^{\mathrm{ns}}$ \\
\hline Potassium (mmol/l) & $3.20 \pm 0.02$ & $3.21 \pm 0.02^{\mathrm{ns}}$ & $3.20 \pm 0.02^{\mathrm{ns}}$ & $3.14 \pm 0.01^{\mathrm{ns}}$ & $3.21 \pm 0.02^{\mathrm{ns}}$ \\
\hline Calcium (mg/dl) & $8.93 \pm 0.01$ & $10.90 \pm 0.01^{* * a}$ & $6.47 \pm 0.02^{* * * b}$ & $8.05 \pm 0.05^{* * b}$ & $7.81 \pm 0.06^{* * * b}$ \\
\hline Magnesium (mg/dl) & $0.78 \pm 0.01$ & $0.83 \pm 0.07^{* * a}$ & $0.76 \pm 0.04^{* * b}$ & $0.79 \pm 0.05^{* * b}$ & $0.77 \pm 0.06^{* * b}$ \\
\hline
\end{tabular}

EEBS: Ethanol extract of B. sensitivum, GM: gentamicin, QTN: quercetin. Values are expressed in mean \pm SEM $(\mathrm{n}=6),{ }^{*} \mathrm{p}<0.05,{ }^{* *} \mathrm{p}<0.01,{ }^{* * *} \mathrm{p}<0.001$ asignificant compared with control group, b-significant compared with GM-induced group ns-not significant.

Table 2: Effect of EEBS on haematological parameters in control and experimental animals

\begin{tabular}{|c|c|c|c|c|c|}
\hline $\begin{array}{l}\text { Parameters studied } \\
\text { (Unit) }\end{array}$ & $\begin{array}{l}\text { Group I } \\
\text { Normal control }\end{array}$ & $\begin{array}{l}\text { Group II } \\
\text { GM } 100 \mathrm{mg} / \mathrm{kg}\end{array}$ & $\begin{array}{l}\text { Group III GM+QTN } \\
50 \mathrm{mg} / \mathrm{kg}\end{array}$ & $\begin{array}{l}\text { Group IV } \\
\text { GM+EEBS } 250 \text { mg/kg }\end{array}$ & $\begin{array}{l}\text { Group V } \\
\text { GM+EEBS } 500 \mathrm{mg} / \mathrm{kg}\end{array}$ \\
\hline $\mathrm{RBC}\left(\right.$ million $/ \mathrm{mm}^{3}$ ) & $7.35 \pm 0.14$ & $6.81 \pm 0.31^{* *} \mathrm{a}$ & $7.22 \pm 0.21^{* * \mathrm{~b}}$ & $6.85 \pm 0.31^{* * b}$ & $7.10 \pm 0.43^{* * b}$ \\
\hline HB (g/dl) & $14.11 \pm 0.28$ & $11.76 \pm 0.58^{* * *_{a}}$ & $14.02 \pm 0.13^{* * \mathrm{~b}}$ & $13.96 \pm 0.21 * * \mathrm{~b}$ & $13.83 \pm 0.31^{* * \mathrm{~b}}$ \\
\hline PCV (\%) & $43.66 \pm 0.52$ & $38.27 \pm 0.81^{* * *} \mathrm{a}$ & $39.58 \pm 0.61^{* * \mathrm{~b}}$ & $38.29 \pm 0.42^{\text {ns }}$ & $38.53 \pm 0.20^{* * \mathrm{~b}}$ \\
\hline MCH (pg) & $20.67 \pm 0.12$ & $20.19 \pm 0.69^{* *} \mathrm{a}$ & $20.84 \pm 0.27^{* * \mathrm{~b}}$ & $20.45 \pm 0.49^{* * b}$ & $20.67 \pm 0.51^{* * \mathrm{~b}}$ \\
\hline WBC $\left(1 \mathrm{X} 10^{3} / \mathrm{mm}^{3}\right)$ & $8.22 \pm 0.41$ & $8.43 \pm 0.33^{* * a} \mathrm{a}$ & $8.21 \pm 0.41^{* * \mathrm{~b}}$ & $8.24 \pm 0.21^{* * b}$ & $8.15 \pm 0.10^{* * \mathrm{~b}}$ \\
\hline Lymphocytes (\%) & $60.05 \pm 0.01$ & $59.96 \pm 0.08^{\text {ns }}$ & $59.97 \pm 0.01^{\text {ns }}$ & $59.96 \pm 0.02^{\text {ns }}$ & $59.96 \pm 0.05^{\text {ns }}$ \\
\hline Monocytes (\%) & $4.97 \pm 0.00$ & $5.00 \pm 0.01^{\mathrm{ns}}$ & $4.96 \pm 0.01^{\mathrm{ns}}$ & $4.97 \pm 0.06^{\mathrm{ns}}$ & $4.96 \pm 0.06^{\mathrm{ns}}$ \\
\hline Polymorphs (\%) & $12.22 \pm 0.21$ & $15.84 \pm 0.11^{* * * a}$ & $14.65 \pm 0.32^{* * b}$ & $14.19 \pm 0.20^{* * \mathrm{~b}}$ & $14.05 \pm 0.11^{* * \mathrm{~b}}$ \\
\hline Eosinophils (\%) & $1.93 \pm 0.01$ & $2.02 \pm 0.01^{\mathrm{ns}}$ & $1.97 \pm 0.08^{\text {ns }}$ & $1.97 \pm 0.02^{\mathrm{ns}}$ & $1.96 \pm 0.01^{\mathrm{ns}}$ \\
\hline
\end{tabular}

EEBS: Ethanol extract of B. sensitivum, GM: gentamicin, QTN: quercetin. Values are expressed in mean \pm SEM $(\mathrm{n}=6),{ }^{*} \mathrm{p}<0.05,{ }^{* *} \mathrm{p}<0.01,{ }^{* * *} \mathrm{p}<0.001 \mathrm{a}-$ significant compared with control group, b-significant compared with GM-induced group ns-not significant.

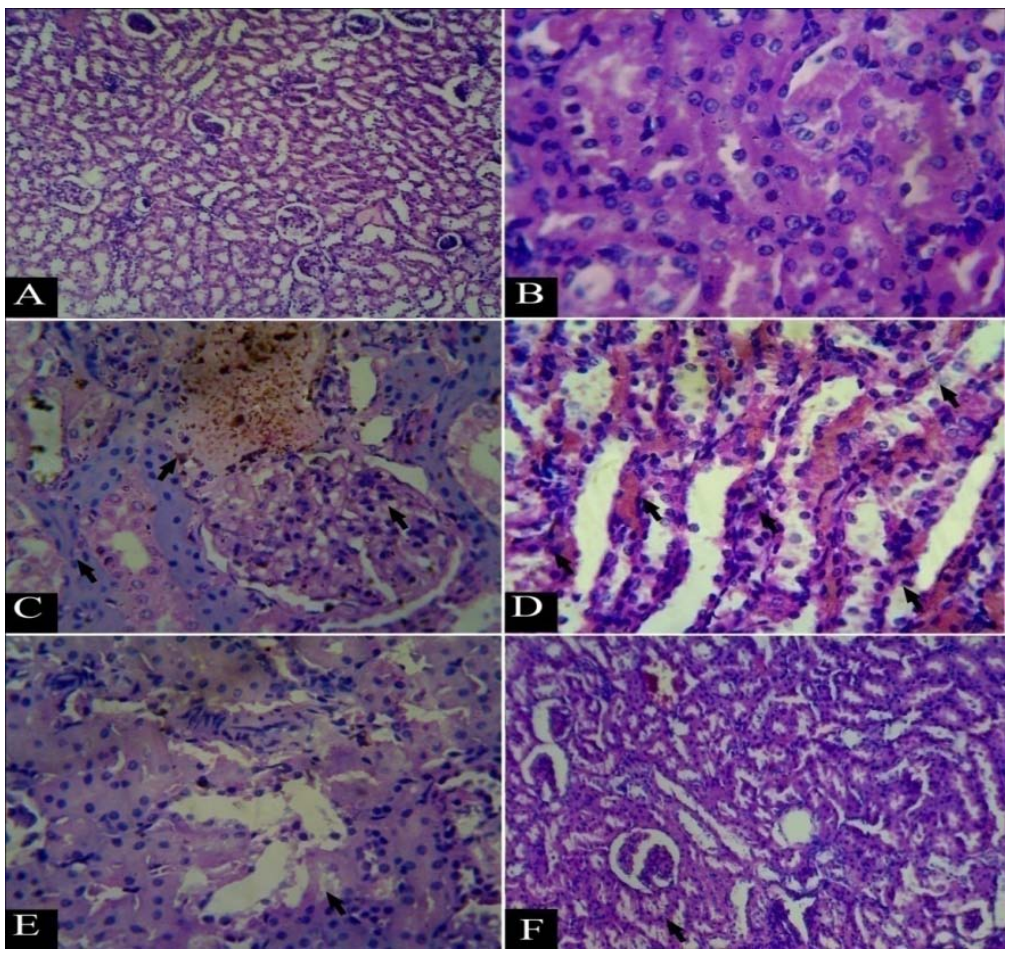




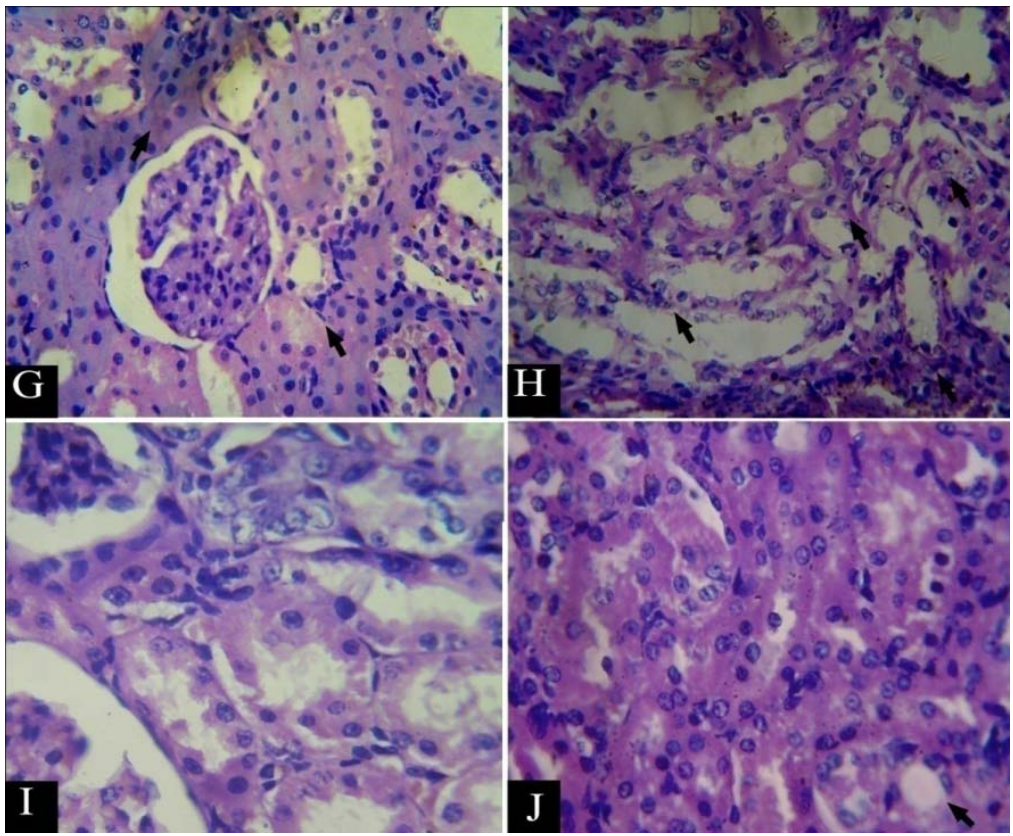

Fig. 1: Histological section of the glomerular and tubular region of kidney stained with haematoxylin and eosin. (A and B) control rat showed normal morphology of glomeruli and tubules. (C and D) Rats received GM $100 \mathrm{mg} / \mathrm{kg} / \mathrm{d}$ (i. p.) for $8 \mathrm{~d}$ with mesangial hypercellularity in the glomerulus, tubular necrosis and tubular degeneration. (EandF) Rats administered with quercetin $50 \mathrm{mg} / \mathrm{kg}(p$. o.)+GM showed mild mesangial hypercellularity in glomerulus but tubules showed no significant pathology. (GandH) Rats received EEBS at dose of $250 \mathrm{mg} / \mathrm{kg}($ p. o. $)+$ GMshowed mild mesangial hypercellularity in the glomerulus, moderate tubular necrosis, tubular degeneration, and cytoplasmic vacuolation. (I and J) Rats received EEBS at a dose of $500 \mathrm{mg} / \mathrm{kg}(p . o$.) $+\mathrm{GM}$ showed no significant pathology except mild cytoplasmic vacuolation in tubules

\section{DISCUSSION}

Progressive weight loss of animals in the GM-treated group has been closely linked to poor feed or water intake. Urine output was significantly reduced in group II animals, however, supplementation of EEBS to GM-treated rats significantly improved body weight, water intake and urine output. GM-induced kidney injury might alter the release of antidiuretic hormone (ADH) or thirst centre activity in the cerebral cortex [30]. Usually, the acidity of urine increases consistently with the degree of kidney injury [31]. However, in this study, there were no significant differences in urinary $\mathrm{pH}$ among animals in all groups. The incidence of elevated levels of urinary excretion of total protein has been suggested as an index of renal damage and proximal tubular dysfunction [32]. In this study, the elevated levels of urinary protein or albumin were significantly reduced by EEBS treatment in rats co-administered with GM. These observations indicated a protective role of EEBS in GM-induced nephrotoxicity.

GM-induced nephrotoxicity has been mainly associated with fall in glomerular filtration rate. Disturbance of electrolyte homeostasis is a less well-documented side-effect of aminoglycoside therapy. GMinduced a rise in urinary excretion of sodium and potassium has been reported previously [33]. Foster et al.,[34] reported that acute GM infusion into rats induced hypercalciuria and hypermagnesemia. In this study, co-administration of EEBS showed a significant reduction in calcium and magnesium excretion, but there were no significant differences in the urinary level of sodium and potassium excretion compared to the GM-treated group. Thus, prevention of hypercalciuric and hypermagnesemic effect may probably be attributed to the protective effect of EEBS in GM-induced nephrontoxicity.

Determination of haematological parameters are considered as the earliest indicator of the deleterious effect produced by the nephrotoxic drug and its metabolite [35]. Exposure of human body to toxic substances may affect multiple organ systems and cause morphological, biochemical and physiological changes, including impaired kidney function and haematological disorders [36-38]. Hematopoietic system is the main target of some drug which adversely affects heme synthesis enzymes, the normal production rate of erythropoietin, normal range, morphology and distribution of various blood cells $[39,40]$. Toxic drugs damage erythrocyte and affect its oxygen-carrying capacity thereby increase the risk of developing hypertension and cardiac arrest [41]. Factors contributing to the pathogenesis of anaemia include shortened RBC survival, marrow suppression by uraemic toxins, iron or folate deficiency. Damage of peritubular cells especially due to the exposure to toxins resulted in inadequate secretion of erythropoietin. In this study, it was observed that haematological parameters were significantly affected due to the administration of GM. Fall in the haemoglobin content, red blood cells counts count, packed cell volume, mean corpuscular hemoglobin level and elevation of white blood cells count and polymorphs were observed in animals in the toxic control group.

These effects may cause defective hematopoiesis, anaemia and weakness in experimental rats. Overall, results of this study suggested that the animals co-administered with standard/extract showed a significant reversal in the haematological parameters that observed in animals in the toxic control group and showed an improvement in hematological status. Ebtihal et al., [42] narrated that that concurrent administration of Acacia senegal with GM reversed the reduction in $\mathrm{Hb}, \mathrm{RBC}, \mathrm{PCV}$ that observed in toxic control animals.

Nephrotoxicity in experimental animals can be confirmed by evaluating pathological symptoms such as tubular degeneration, desquamation, necrosis, intertubular haemorrhage, the presence of hyaline casts in tubules, congestion and swelling in glomerulus [43]. In this study, treatment with GM caused acute renal damages which were evident by marked mesangial hypercellularity in glomerulus, focal tubular epithelial loss and blood vessel congestion, compared to animals in control group.' These changes were reduced in EEBS-treated groups which were evident from mild cytoplasmic vacuolation in the proximal tubules, thus showing a protective effect of the drug. It was observed that amelioration of GM-induced renal injury was more insightful in rats treated with $500 \mathrm{mg} / \mathrm{kg}$ of EEBS. 


\section{CONCLUSION}

The phytochemical screening of EEBS revealed the presence of carbohydrates, alkaloids, steroids, saponins, proteins, amino acids, flavonoids, tannins, phenolic compounds and fixed oils. EEBS treatment restored GM-induced proteinuria, albuminuria and disturbances in urinary level of calcium and magnesium, body weight, water intake and urine output. Co-therapy with EEBS showed a significant reversal in the hematological parameters that were observed in animals in the toxic control group and exhibited improvement in hematological status. Histopathological examination of kidneys substantiated the results obtained from in vivo evaluation of nephroprotective activity in animals. These observations indicated that the nephroprotective activity of the extract might be due to the presence of phenolic and flavonoid content and its antioxidant nature. However, further studies are required to isolate the phytoconsitutents and confirm these findings.

\section{ACKNOWLEDGEMENT}

We acknowledge Dr. R. Sambathkumar, Principal of J. K. K. Nattraja College of Pharmacy, Dr. Vijayabhaskaran, Department of Pharmaceutical Chemistry J. K. K. Nattraja College of Pharmacy for their enormous encouragement and guidance.

\section{FUNDING SOURCES}

This research did not receive any specific grant from funding agencies in the public, commercial, or not-for-profit sectors.

\section{DISCLOSURES}

The authors declare no conflict of interest. All the authors declare that they had no financial, personal relations towards other organisations whose interest could have affected the content of the article in either positive or negative way.

\section{AUTHORS CONTRIBUTIONS}

Abhirama. B. R. wrote the primary draft of this paper and did the statistical analyses, which was edited by Dr. Shanmuga Sundaram R for essential content. Dr. Raju A helped with the review of the paper for a improved quality. All the authors reviewed and provided comments on further iterations.

\section{REFERENCES}

1. Ho JL, Barza M. Role of aminoglycoside antibiotics in the treatment of intra-abdominal infection. Antimicrob Agents Chemother 1987;31:485-91.

2. Edson RS, Terrell CL. The aminoglycosides. Mayo Clin Proc 1999;74:519-28.

3. Lerner SA, Schmitt BA, Seligsohn R, Matz GJ. Comparative study of ototoxicity and nephrotoxicity in patients randomly assigned to treatment with amikacin or gentamicin. Am J Med 1986;80:98-104.

4. Abdel-Raheem IT, Abdel-Ghany AA, Mohamed GA. Protective effect of quercetin against gentamicin-induced nephrotoxicity in rats. Biol Pharm Bull 2009;32:61-7.

5. Bhattacharjee S. Reactive oxygen species and oxidative burst: roles in stress, senescence and signal transduction in plants. Curr Sci 2005;89:1113-21.

6. Ozbek E, Ilbey YO, Simsek A, Cekmen M, Mete F, Somay A. Rosiglitazone, peroxisome proliferator receptor-gamma agonist, ameliorates gentamicin-induced nephrotoxicity in rats. Int Urol Nephrol 2010;42:579-87.

7. Shin HS, Yu M, Kim HS, Choi HS, Khang DH. Renoprotective effect of red ginseng in gentamicin-induced acute kidney injury. Lab Invest 2014;94:1147-60.

8. Editorial Committee of the Flora of Taiwan. Flora of Taiwan. $2^{\text {nd }}$ ed. Vol. III. Taipei: Epoch Pub; 1993.

9. Yun LL, Wan YW. Chemical constituents of Biophytum sensitivum. Chin Pharm J 2003;55:71-5.

10. Leopold J, Gerhard B, Mohamed SP, Beena J. Medicinally used plants from India: Analysis of the essential oil of airdried Biophytum sensitivum (L.) DC. Sci Pharm 2004;72:87-96.

11. Guruvayorappanc C, Afira AH, Girij K. Antioxidant potential of Biophytum sensitivum extract in vitro and in vivo. J Basic Clin Physiol Pharmacol 2008;17:255-67.
12. Natarajan D, Shivakumar MS, Srinivasan R. Antibacterial activity of leaf extract of Biophytum sensitivum (L.) DC. J Sci Res 2010;2:717-20.

13. Puri D. Screening of mildly hypoglycemic compounds: obese British Angora rabbits with borderline glucose intolerance as an animal model. Indian J Pharm Sci 2006;68:579-83.

14. Guruvayoorappan C, Kuttan G. Amento flavone inhibits experimental tumor metastasis through a regulatory mechanism involving MMP-2, MMP-9, prolyl hydroxylase, lysyloxidase,VEGF, ERK-1, ERK-2, STAT-1, nm23 and cytokines in lung tissues of C57BL/6mice. Immunopharmacol Immunotoxicol 2008;30:711-27.

15. Jachak SM, Bucar F, Kartnig T. Anti-inflammatory activity of extracts Biophytum sensitivum in carrageenin-induced rat paw edema. Phytother Res 1999;13:73-4.

16. Puri D. Hypocholesterolemic effect of Biophytum Sensitivum leaf water extract. Pharm Biol 2003;41:253-8.

17. Azhar-Alam MM, Javed K, Jafri MA. Effect of Rheum emodi (Revand Hindi) on renal functions in rats. J Ethnopharmacol 2005;96(1 Suppl 2):121-5.

18. Rajesh KS, Rajani GP, Vivek S, Komala N. Effect of ethanolic and aqueous extracts of Bauhinia VariegataLinn. on gentamicininduced nephrotoxicity in rats. Indian J Pharm Edu Res 2011;145:192-8.

19. Kirtikar KR, Basu BD. Indian medicinal plants. $2^{\text {nd }}$ ed. Vol. I. Dehradun: International Book Distributors; 1999. p. 1045-8.

20. Harborne AJ. Phytochemical methods. A guide to modern techniques of plant analysis. $3^{\text {rd }}$ ed. Springer Sciences and Business Media; 1998. p. 334.

21. Anindya B, Md Harun AR, Abdur R, Tapas KP. In vivo screening of ethanolic extract of Biophytum sensitivum DC leaves on peptic ulcer induced by aspirin in wistar albino rats. Int J Pharm Phytopharmacol Res 2014;3:418-22.

22. Lowry $\mathrm{OH}$, Rosebrough NJ, Farr AL, Randall RJ. Protein measurement with the Folin-phenol reagent. J Biol Chem 1951;193:265-75.

23. Reinhold JG. Total protein, albumin and globulin. Stand Methods Clin Chem 1953;1:88-97.

24. Maruna RF, Trinder SR. Determination of serum sodium by colorimetric method. Clin Chim Acta 1957;2;581-5.

25. Maruna RFL. Determination of serum potassium by colorimetric method. Clin Chem Acta 1957;2:131-3.

26. Lorenz K. Improved determination of serum calcium with orthocresolphthalein complex one. Clin Chim Acta 1982;126:327-34.

27. Heaton FW. Determination of magnesium by the Titan yellow and ammonium phosphate methods. J Clinl Pathol 1960;13:358-60.

28. Ramnic S. Textbook of medical lab technology. $1^{\text {st }}$ ed. New Delhi: Jypee; 2007. p. 204-21.

29. John MB. Laboratory medicine hematology. $4^{\text {th }}$ ed. ST Louis: CV Mosby Co; 1972. p. 1198-204.

30. Desouza VB, de-Oliveira RFL, de-Lucena HF, Antunes AA, Guerra GCB, Freitas ML, et al. Gentamicin induces renalmorphopathology in Wistar rats. Int J Morphol 2009;27:59-63.

31. Li CC, Finley DS, Uribe C, Eichel L, Lee DI, McDougall EM, et al. Effect of urine specific gravity on the effectiveness of shockwave lithotripsy. J Endourol 2005;19:167.

32. Wolf G, Ziyadeh FN. Cellular and molecular mechanisms of proteinuria in diabetic nephropathy. Nephron Physiol 2007;106:26-31.

33. Derakhshanfar A, Bidadkosh A, Kazeminia S. Vitamin E protection against gentamicin-induced nephrotoxicity in rats: a biochemical and histopathologic study. Iran J Vet Res 2007;8:231-8.

34. Foster JE, Harpur S, Garland HO. An investigation of the acute effect of gentamicin on the renal handling of electrolytes in the rat. J Pharmacol Exp Ther 1992;261:38-43.

35. Paprika MV, Sharma BB. Protective effect of sesame oil against lead acetate induced hematao-biochemical toxicity in albino rats. J Cell Tissue Res 2003;3:12-7.

36. Patocka J, Cerny K. Inorganic lead toxicology. Acta Medica (Hradec Kralove) 2003;46:65-72.

37. Lavicoli I, Carelli G, Stanek EJ, Castellino N, Calabrese EJ. Effects of low doses of dietary lead on red blood cell production in male and female mice. Toxicol Lett 2003;137:193-9. 
38. Ashour AA, Yassin MM, Abu Aasi NM, Ali RM. Blood, serum glucose and renal parameters in lead-loaded albino rats and treatment with some chelating agents and natural oils. Turk J Biol 2007;31:25-34.

39. Sharma R, Panwar K, Mogra S. Alterations in developing RBCs after prenatal and postnatal exposure to lead acetate and Vitamins. Int J Pharm Sci Res 2013;4:3214-24.

40. Adikwu E, Deo 0, Geoffrey, OBP, Enimeya DA. Lead organ and tissue toxicity: roles of mitigating agents (Part 1). Br J Pharm Toxicol 2013;4:232-40.
41. Vaziri ND, Liang K, Ding Y. Increased nitric oxide inactivation by reactive oxygen species in lead-induced hypertension. Kidney Int 1999;56:1492-8.

42. Ebtihal ET, Sania AS, Muddathir AK, Muha MEA. Nephroprotective effect of Acacia senegal against gentamycininduced renal damage in rats. World J Pharm Res 2016;5:294303.

43. Polat A, Parlakpinar H, Tasdemir S, Colak C, Vardi N, Ucar M, et al. Protective role of aminoguanidine on gentamicin-induced acute renal failure in rats. Acta Histo Chem 2005;108:365-71. 